\title{
THE DIALECTICS OF “ORIENTAL” IMAGES IN AMERICAN TRADE CARDS
}

\author{
Sue J. Kim \\ University of Alabama, Birmingham
}

A late nineteenth-century trade card, or a color-printed circulating advertisement, touts Shepherd and Doyle's new "Celluloid" waterproof collars, cuffs and shirt bosoms (Fig. 1). ${ }^{1}$ These "economical, durable, and handsome" clothing items require less starching and washing, and so remove the need for Chinese laundries. The text on the reverse side includes directions on how "to remove yellow stains," and the image enacts a kind of literal version of this removal. The slovenly laundryshop (the clothes overflowing the basket, the linens hung up askew, the steaming basins), the mix-and-match, gender-ambiguous garments of the workers, and their thin, slouching bodies all participate in the racist stereotype of Asians as dirty, effeminate and alien others. The caption proclaims the product to be "The Last Invention"; the "last" indicates finality, both in terms of modernity as the final stage of history and of a solution to the problem of unwanted immigrants. A group of Chinese male laundry-workers are so taken aback by this product that their pigtails stand in erect consternation. Their reaction stems both from the realization that they must return to China because their services have become unnecessary as well as 


\section{Ethnic Studies Review Volume 31}

from pure awe at the invention itself; in both cases, the scenario and its appeal apparently rely on these acts of recognition by the Chinese characters. Furthermore, the advertisement's status as such - merely advertisement - hides the illogicality of the celluloid salesman's presence in the laundry at all. The salesman, wearing a garish plaid suit and a bowler hat, appears to be one of those traveling salesmen who might peddle patent medicines, yet he bears the product eliciting such awe and consternation. Rather than selling the product to the Chinese workers, he appears simply to be taking gratuitous pleasure in introducing the workers to the agent of their impending misfortunes.

This example suggests the "work" of such trade cards in a number of ways. The erect queues, figures of fetishistic fascination for the American public, signal both fear and desire. And like the Chinese workers' relation to the product in the center, the viewer assumes a role of both repulsion and identification with the Chinese figures, the salesman, and the product. The viewer is supposed to desire the object, but unlike the Chinese, the viewer should not fear it. The viewer, alternately, should identify with the salesman, but, particularly to middle-class consumers to whom such products are directed, he is not a figure of refinement and style. Modern technology forces the Chinese out and "cleanses" the nation of racial others, but the images also produce an anxiety of identification through the fear of being forced out of work by technological advancements. Such advertising images participate in the construction of the Other - national, sexual, racial, class, etc. - but their appeal is also often based on an uncanny identification with those figures of otherness, betraying an anxiety about those demarcations and differences. This particular card (Fig. 1) fantasizes a solution to the problem of Chinese immigration as a salve to anxieties over national and racial purity. At the same time, the card appeals to the middle-class's anxiety to distinguish itself from others, partly in the valuation of cleanliness and technology, partly in the collection of Oriental objects. The cards provide a cheap and accessible way to access this middle-class cultural capital; unlike valuable Asian art and collectibles, or the Oriental rugs, furnishings, screens, fans, and other items the upper class displayed 


\section{Kim-Dialectic of "Oriental” Images}

in their living rooms, these cards circulated freely and widely. So although the figure of the Oriental is usually theorized as serving as an "other" for national identity as well as modernity, figures of the Orient and Orientals in trade cards help form national, modern, consumer, and_class consciousness; - by complex dialectics and situational variances of sameness and difference, identification and repulsion. ${ }^{2}$ That is, while trade card images were certainly part of the racist imperialist project that was central to the construction of American identity, many images also betrayed the anxiety over the failure of those divides in time and space and over the agency of the other.

In this paper, I examine the ways in which such trade cards served as fetishes in psychic, social, and economic systems. The consumer's fixation on the fetish object hides the ideological cultural work that creates the desire for the object, desire that is driven by lack and anxiety that are impossible to satisfy. In essence, I am asking what Thomas Kim asks, but of less exalted objects than the decorative furnishings that he studies. He writes, "It seems clear that Oriental objects and Oriental displays functioned as enticements to consumers, but why and how did they serve this function in modern consumer culture?"3 To explore these questions, I will explore the ways in which trade card images negotiate the complex, multiple dialectics at work in the creation of sometimes contradictory American national identities, particularly the middleclass. Robert Jay finds that trade cards gave the impression that "all Chinese in American were engaged in laundry work," and that the U.S. fascination with all things Japanese was mobilized to sell luxury items and soap, but the cards often fail to be so clearly demarcated. ${ }^{4}$ It is true that images of the Chinese tended to take the form of laborers in the U.S. while figures of the Japan tended to be of kimono-clad women in faraway places, but China also figures as an exotic faraway land, vaguely connected to Japan. Furthermore, the figures of Chinese Americans are not always so obviously grotesque as in Fig. 1. The appeal of the images and their ideological import, depending on context, can be explicable although perhaps unexpected according to our current reading paradigms. 


\section{Ethnic Studies Review Volume 31}

\section{The Dialectics of Trade Cards}

Trade cards circulated widely in the late nineteenth century. The development of cheap, full-color printing in the 1870s replaced woodcuts and copperplate engraving methods used in the seventeenth and eighteenth centuries.5 This enabled mass advertising campaigns that increased the popularity of these cards, which usually featured a color illustration on one side and text on the other. 6 Because they could make use of color printing at a time when color advertisements in periodicals were rare and because they were relatively inexpensive to produce, by the $1880 \mathrm{~s}$ and 90s, trade cards were the most popular form of advertising in America.7 Included with the product package or distributed by local shopkeepers, trade cards reached more households than any other medium. With the introduction of lithography in the early nineteenth century and improved transportation, smaller towns also began printing their own cards and publications, but the majority of trade cards were produced in the northeast. 8

These trade cards, Jay notes, were "an essentially private medium," meant to be viewed by the individual consumer and even collected and "cherished." ${ }^{\prime \prime}$ At the same time, trade cards were public, everywhere; in many respects, their effect worked through a number of such apparent contradictions. Much has been written about the role of popular culture in creating national, racial, and/or imperial identities through the exclusion of others. Anne McClintock argues that the unprecedented production and dissemination of advertisement contributed to the culture of modernity in "the discovery that by manipulating the semiotic space around the commodity, the unconscious as public space could also be manipulated."10 "Imperial kitsch as consumer spectacle," she writes, "could package, market, and distribute evolutionary racism on a hitherto unimagined scale. No preexisting form of organized racism had ever before been able to reach so large and so differentiated a mass of the populace."11 Racial discourses worked to define not only the home-nation citizenry and, increasingly, a distinct middle class, but also "dangerous" or marginal groups, like workers, Irish, prostitutes, feminists, gays and lesbians, etc. ${ }^{12}$ In the U.S., Lisa Lowe argues that "the state has estranged Asian immigrants 


\section{Kim-Dialectic of "Oriental" Images}

through racialization and bars to citizenship, thus distancing Asian Americans, even as citizens, from the terrain of national culture."13 Such quests for authenticity become particularly important yet also impossible in modernity.

As Walter Benjamin has pointed out, part of the mark of modernity lies in the decline of art's aura, or the hallowed singularity of a particular original work of art. The ready reproducibility of images increases their accessibility and seriality, so their ideological work becomes increasingly flexible and uncertain. ${ }^{14}$ The only constant is that these images would indeed be manipulated. Elizabeth Kim finds in her study of trade cards in eighteenth-century Britain that, although representations of Asians, Africans, and American Indians varied widely and even contradicted one another, such racial images were invariably subsumed by imperial and capitalist interests. That is, the flexibility and variability of the images arise from the specific advantage to be gained in a commercial and political situation. ${ }^{15}$

So, certainly, these cards had practical (advertising) and ideological intents; as Richard Ohmann notes in his study of nineteenth-century advertisements, "without question the 'you' of these ads could read these images; if not, advertisers were paying for indecipherable communications." ${ }^{\prime 16}$ But the ideological effects of any cultural product cannot be easily or uniformly determined. Jennifer Wicke points out that despite their intent, many factors influenced the actual effects of the cards, including individual differences, institutions, collectives, forms and genres, political economy, etc,; certainly, advertising images are "overdetermined." ${ }^{\prime 17}$ As Linda Frost argues in Never One Nation, the regional press and local conceptions of identity in varying degrees of tension with other regions and an overall "national" identity vastly complicate our understanding of the ideological work of popular culture. ${ }^{18}$ Contexts of reception and various discourses and structures shape how and what a trade card could mean.

Furthermore, even if uniform reception were possible, the images of "the Orient" do not serve only as an Other. Thomas Kim argues that the Orient was a "fungible" concept that played a vital role in negotiating the modern U.S. consumer's ambivalent attitude toward imperialism and consumerism. Rather than simply 


\section{Ethnic Studies Review Volume 31}

constructing a premodern, faraway other, the notion of an Orient in close proximity was integral to creating modern consciousness, including consumerism and a critical attitude towards it. The ostensible aestheticism of the Orient licensed Westerners' consumption and control of Oriental things, while the figure of the devious Oriental overcome by his desire for beautiful things, usually white women, appealed to U.S. audience's anxieties about overconsumption. Thus, the Orient-as-concept functions by permeability between self and other, past and present, "here" and "over there," subject and object, and consumer and consumed. Rather than simply casting a uniform Other to a uniform Self although they may apparently try to - the dialectics driven by anxieties and contradictions become constitutive of American identities. These dialectical tensions include the middle-classes' desire to distinguish itself from the lower and upper classes, despite also wanting to share some of their qualities; the attempts of the nation, post-Civil War, to define itself against slavery and for free labor; and the vain attempt of sexual and gendered regulation.

While the ostensible threat of Chinese labor was to the working class, trade cards such as Fig. 1 seemed to appeal to the middle class on the basis that the product would rid the nation of cheap labor. Other cards, however, used the figure of the Chinese laundry worker to embody middle-class values of economy, thrift, and convenience. In other words, the racial imaginary of the nation was malleable according to the exigencies of nationhood and business, or what David Harvey and G. Arrighi refer to as the competing logics of territory and capital. ${ }^{19}$ Particularly for the middle class, trade cards served multiple, complex functions.

As the twentieth century dawned, U.S. national culture increasingly centered on a growing middle class, differentiated from the working classes and immigrants as well as the decadent robber barons. Consumption, which played a central role in the middle-class's self-definition, was not a simple thing. It worked differently across class lines, and particularly for the middle class, consumption served as a mark of distinction. Around 1900, a millworker's family making around $\$ 500$ per year would only be able to purchase products for necessity, survival, and a "hard-won 
decency," while an engineer's family, making around $\$ 2,000$ per year, would live with "distinction," a "higher life" dictated not only by necessity but also respectability. ${ }^{20}$ The growing professionalmanagerial class, comprised of "professionals, 'petty proprietors,' managers, and officials," sought to define its identity and status," thinking "more in terms of mobility and merit than in fixed lines and antagonisms." ${ }^{21}$ In 1893, modern conveniences and brandname products, such as "packaged cereal and crackers, canned vegetables and fish, packed meat, ketchup, [and] soft drinks," were "distinguishing mark[s] of class" for such households. ${ }^{22}$ The desire for class distinction entwined with fear of the lower classes as unruly mobs. In the debate over Asian immigration, the working class was depicted as an ignorant racist mob; in the minds of the middle class that desired stability and a stable identity for itself, labor unrest was a boiling cauldron threatening to overflow.

Thomas Kim notes that while African and Native objects were shown at museums and collected by private collectors, Oriental art in middle-/upper-class homes stood as "exemplars of cultural refinement and the highest aesthetic aspirations." He argues that these were not merely spectacles of the primitive or premodern, but signaled that the consumer had cultural capital in the form of "an education in beauty, an appreciation of 'nature,' and a training of the aesthetic sense"; in other words, "The Oriental object figured into a project of education and even uplift." ${ }^{23}$ The consumption and production of putative Oriental art, such as middle-class girls painting Oriental fans, was part of the growing modern middleclass self-definition through refinement and mobility. Images of an aestheticized, traditional, objectified Orient in trade cards functioned in even more divergent and unpredictable ways. Their appeal was based on the popularization of the notion that possessing Oriental objects and art constitutes a mark of high culture, yet their form hardly carried the same kind of cultural cachet as a piece of furnishing or a skill like painting fans. Trade cards were accessible to everyone. At the same time, the middle-class consumer could collect these trade cards as a sign of their upper-class taste. In essence, while the cards illustrate the ways in which elite tastemakers can shape popular culture, they also testify to the instability 


\section{Ethnic Studies Review Volume 31}

of such racialized images.

At the same time, the middle class also wanted to distinguish itself from the decadent overconsumption of the robber baron class, in part through possession of those values like economy and thrift that it shared with the more acceptable elements of the working class. The middle class was engaged in a complicated dance of self-definition, in which identification and differentiation with the working and upper classes played a key role, and trade cards were a key form of currency in this system of ideological exchange.

Another part of this process was the ongoing negotiation between freedom and slavery. Moon-Ho Jung discusses how, after the Civil War, the discourse in which the figure of the coolie embodied slavery and was distinguished from free immigrants set the ground for 1882 Chinese Exclusion Act. ${ }^{24}$ This was also part of the U.S.'s self-definition as the defender of freedom, which in turn helped justify American imperialism in Southeast Asia. This project involved not only the casting out of the racial others, but also the anxious recognition of the continuation of slavery in a nation that increasingly defined itself in terms of freedom, despite its origins in slavery. This anxiety was distinct from the threat of "cheap Chinese labor," which ostensibly could be free but unwanted competition. Rather, the phenomenon Jung describes stems from what Miller calls the "coolie fiction," or the notion that all Chinese labor was enforced, which led lawmakers and others to oppose Chinese immigration. ${ }^{25}$

Furthermore, several scholars have examined the ways in which Asian bodies, particularly male bodies, posed threatening ambiguities to the already-precarious constructions of regulated sexuality and gender. ${ }^{26}$ The images in the trade cards play on the dialectic between regulated and "deviant" sexuality. Despite the power of sexual regulations, regulated sexuality can never really stay regulated because, like Simone de Beauvoir's woman, the subject insists on being an agent, even in fulfilling its prescribed role as object. The very fact that gender and sexuality are roles, as Judith Butler points out, destabilizes them even as they are embodied. So even as sexed, gendered, racialized national and class identity were formed through the figuration of others, this 
very figuration testifies to the anxiety of those identities. The figure of the other may exhibit uncomfortable similarities that, of course, fuel the very need for those distinguishing acts.

In the following sections, I will examine the complex negotiations taking place in three themes of trade cards featuring Oriental images: the American, modern, technological innovation as "cleansing agent" (Figures 1 to 8); the "benign" images of domesticated Orientals and the benevolent American supernational super-man (Figures 9 to 15); and the figures of the classic Orient, particularly in the form of nature and women (Figures 16 and 17).

\section{Modernity as Cleansing Agent}

As seen in the example of the collar advertisement, the invention of various technological advances, such as cold-handle irons and celluloid, waterproof linens, serve to rid the U.S. of "cheap Chinese labor." One advertisement calls this "the handwriting on the wall" (Fig. 2). The product becomes the agent, enabling the various figures of the U.S. to banish unwanted immigrants. As Anne McClintock notes, the domestic commodity becomes not only the symbol of but also the agent of progress. ${ }^{27}$ In her study of soap advertisements, she finds that white women and Africans "are figured not as historical agents but as frames for the commodity, valued for exhibition alone." 28 At the same time, the scenario - in the advertisements as well as the in real life - is a strange one, as the ostensible competition between white American and Asian American workers would not have primarily been in the laundry business, but in the heavy industries. While it is true that, in the 1890s, active campaigns encouraged steam laundries at the expense of Chinese-owned hand laundries, American labor unions were not primarily concerned with these occupations. ${ }^{29}$ These celluloid collars and new irons would alleviate the burden of domestic work and reduce the cost of laundering, but the rhetoric about cheap Chinese labor was that it would deprive American workers of jobs. However, American workers, particularly men, were not vying for laundry jobs; it was (and is) considered unpaid domestic labor. Not only does the cultural imperative of nativist racism take precedence over the realities of big business, Thomas 


\section{Ethnic Studies Review Volume 31}

Kim argues that this obscuring of material relations and histories in fact characterizes modernity.

The upset laundry worker in Figure 2 apparently shares the consternation of the workers in Figure 1. In this illustration, Columbia, bearing the shield of "Invention," points to the "handwriting on the wall" as well as the space outside the picture. The actual words on the wall read "No more Chinese cheap labor / Celluloid cuffs, collars \& bosoms," while the caption at the bottom of the image interprets it as "Othello's occupation gone." In this ad, the actual product does not appear; rather, we have a triangulated relationship between Uncle Sam, Columbia, and the Chinese worker. Columbia, as the guardian of civilization and standard-bearer of progress must "cleanse" the unsavory elements, which in this ad as in Fig. 1, includes not only the Chinese laundry worker himself but also the disarray of his shop (the upturned basin as chair, the spilled box of starch, the overturned iron, the baggy clothing). Columbia and the Chinese laborer enact a scenario for a pleased Uncle Sam, gazing in through the window.

On one hand, this scene relegates the Orient to the past, outside the margins of modernity. At the same time, the figure of Uncle Sam in the background suggests that this "scene" helps constitute Americanness. American identity relies on an anxious dialectic between here/there, self/other, subject/object, and modern/primitive. The Chinese laundry worker lives in the U.S.; that fact, and the tensions arising from it, give rise to the caricature. Uncle Sam gazes lovingly at Columbia and possibly even identifies with her, but they are not the same person; there is a space of disidentification. Columbia indicates the "writing on the wall" for Uncle Sam as much as the laundry worker and the viewer.

Two additional considerations complicate this image. First is the vaguely "Oriental" lettering on the wall behind the laundry worker. This could also be read as the "handwriting on the wall" that means "Othello's occupation gone." If this is so, this suggests that the pleasure or appeal of the ad relies not only on the objective situation, but, as in Fig. 1, on the devastating realization of the laundry worker and perhaps even his writing his lamentations on the wall. This assumes not simply that he is a primitive other, but a 


\section{Kim-Dialectic of "Oriental" Images}

rational being who evidently understands the handwriting on the wall. Rather than simply othering the Chinese figure, this image shows him as a rational being who must accept the superiority of U.S. technology. Uncle Sam may so love Columbia because she provides the external justification for imperialism (technological superiority) for which he has been searching. We return again to the notion that the appeal of the ad plays a more complex role that simply banishing the other; a complex dialectic between sameness and differentiation is taking place. It suggests an acknowledgement, at some level, of the agency and voice of the writer, and at some levels, this rationality, agency, and ability are necessary to justify the superiority of the West. ${ }^{30}$

Furthermore, the inscription identifies the Chinese laundry worker with Othello, Shakespeare's hubristic Moorish king. The ad aligns the laundry worker with a non-white who not only aspires to power and greatness but is powerful and great, but who is destroyed by his pride and jealousy. Again, Othello is an "other," but he also the figure of identification for the reader, moreso than Desdemona or Cassio. Again, the trade card works through subtle, simultaneous, and contradictory signals. While the text attempts "anchorage" to guide interpretation and meaning, slippage inevitably occurs. ${ }^{31}$ The image places a distance between the agent, the desired, and the other, but the process of reading the images also incorporates moments of an uncomfortable yet enjoyable recognition of sameness.

Figures 3 and 4 more overtly constitute American masculinity through not only the sheer inventive technology of these new celluloid collars, but also the tough-yet-stylish imperviousness to nature of this technology. In both figures, a Chinese figure looks on as a white man stands fully dressed in the water, demonstrating the waterproof feature of his new linens. Fig. 3 states, "No more washee washee - Melican man wear celluloid collar and cuffs." Because the Chinese laundry workers' services will no longer be necessary, in Fig. 3 the Chinese are "off for China." In Fig. 4, a boat in the distance indicates more subtly the suggested route for the Chinese onlooker. Both these illustrations feature another triad, in which the gaze of the Chinese onlooker functions in tandem with 


\section{Ethnic Studies Review Volume 31}

the gaze of another onlooker, an additional white man to the left who admires the celluloid-linen-wearing alpha male in the center of the picture. In Figure 3, the ancillary man points to the hearty "Melican man" that the Chinese worker, the viewer, and, judging from the pleased looked on his face, he himself are supposed to register as the new epitome of manhood. In Fig. 4, the third man sits in contrast to the man in the center. Wearing an oldfashioned collar, he is short, rotund, wrinkled, and sweating; at the mercy of the elements, he carries a parasol. The effeminacy evoked by the parasol and the man's corpulence connects him to the overconsumptive, effete upper class. In contrast, the central man wearing the economical and practical celluloid linen stands impervious to the elements. The ad helps construct middle-class American masculinity by contrasting it not only with the racialized other but also with the white man who lacks the practicality of celluloid linens and its attendant toughness.

Figures 5 and 6 likewise tie together bourgeois practicality, style, masculinity, and Americanness. On the front of the card, Fig. 5, a destitute man kneels on the floor before his drawers overflowing with dirty linens, while the Chinese laundry worker sits slightly above him on a stool. The caption reads, "Plenty dirtee shirtee / but john no washee more / tillee payee threely dollee / you owee john before." On the reverse, shown in Fig. 6, the roles have changed. The white man is nattily dressed and standing tall; he has even gained another drawer in his bureau. The Chinese figure cowers before him, as he is told, "Look at this collar and these cuffs, John / You may well scowl and pout / Celluloid don't need washing John / so take your cue and get out." The pun on "cue" and "queue" conveys repulsion and satisfaction, but again, the image conveys ambivalent feelings about acquisition. On one hand, for the white male character, the product offers upward mobility; according to this trade card, being poor and being at the mercy of an Oriental are indignities compounding one another. On the other hand, the love of money, or the apparent greed of the Chinese figure, is portrayed as repellant. Upward mobility and the acquisition of money are essentially portrayed as two separate things. This licenses the flexibility and accumulation of middle- 
class wealth by distancing it from crass greed.

Figures 7 and 8 also feature a product that rids the U.S., and an industrialized, commercially thriving California in particular, of hordes of indistinguishable Chinese. The Asian figures display the distinguishing characteristics shared by the other trade cards: long queues, slanted eyes and dramatic eyebrows, long fingernails, small, gender-ambiguous but invariably male bodies, identical loose shirts and baggy pants, slippers, and grimaces. Fig. 7 shows Uncle Sam being chased by a group of Chinese crying "stopee Melican Man!" The ad tells us that the "best way to get the Chinese back home" is to "take them Mrs. Potts sad irons." California is depicted as a sprawling industrial center, while China is enclosed, backwards, and traditional. In Figure 8, Columbia wields a "new style" iron while a Chinese figure, holding an "old flat iron," boards a boat labeled "For China Direct." In both these instances, the cleansing agent of modern technology is needed to reinforce spatial and temporal boundaries that the presence of the Chinese into the U.S. has violated. These images construct the U.S. as much as the Chinese; both Uncle Sam and Columbia wields the new technologies that help distinguish them from the other.

\section{Benign Orientals and Benevolent Super-national Supermen}

In contrast to the images above, some advertisements portray benign images of Asians, both within the U.S. as well as outside the U.S. Particularly when Orientals are cast as representatives of their nation or part of the world, they become not only harmless but almost equivalent to other nations as one among many. At the same time, both these images of benignity and benevolence enable differentiating moves that justify U.S. superiority, in part (individuals, a class) or as a whole nation.

"Benign" images of Asians in the U.S. portray them as "domesticated," in both senses of tamed as well as engaged in women's work. The "benign" images offer no scenario of cleansing but rather appropriate the "Chinese" and Oriental into the fabric of American life, both in the content and form of the trade cards. I put "benign" in quotes because of course they are actually 


\section{Ethnic Studies Review Volume 31}

patronizing, infantilizing, racist caricatures, and yet their intent is to reference positive qualities through these figures of the Chinese. The conflation of "Chinese" and "female" or "domestic" reappears in Figure 9, in which a gender-neutral Chinese and a white woman share a bonding moment over the joys of C.T. Reynolds Liquid Blue dye. The Chinese character is "genderless" because, while the text on the reverse side refers to "Housekeepers and Laundresses," he/ she exhibits the characteristics of male Chinese laborers, as in the ads discussed above. The woman is presumably a housekeeper and/or working-class laundress. The two figures, not dainty and refined but rather work-a-day and unglamorous, personify industry (as workers), familiar figures who know about the care of clothes, and this ad works by negotiating identification with and distinction from these figures. While the middle-class consumer presumably identifies with the expertise of these two figures, he/she could also see these figures as benign others.

Another image linking domestic work and Chinese labor appears in Figure 10, which advertises the sole sellers of "Rachel's Enamel Bloom" in San Francisco (this image was also used to advertise a fine clothing and tailoring store in Philadelphia). The ad offers little logical or narrative connection between a Chinese laundry worker and the product, but the image connotes industry, hard work, and quality, or, as the text in Figure 1 puts it, "convenience, neatness, and economy." This replaces the distaste for slovenly laundry workers with the sense of familiarity and comfort found in Fig. 9. Furthermore, in this advertisement, the text directly above the Chinese figure's head reads "absolutely harmless." Although this caption is supposed to refer to the product, it also reinforces the sense of safety and comfort with this figure. Interestingly, this particular image was copyrighted in 1882, the year of the first Chinese Exclusion Act, indicating the range of attitudes toward and discourses about Asian during that time. George Seward (1881), Otis Gibson (1881), and others argued at the time that Chinese labor was valuable and that Chinese ethics were compatible with American values. So the figure of the Chinese laundry worker was flexible enough to use for a variety of purposes.

Figures 11-13 also use cartoon-like situations involving the 


\section{Kim-Dialectic of "Oriental" Images}

classic laundry shop and queues, and the familiarity and flexibility as well as violence and darkness of these images recall folk figures like Uncle Remus and Brer Rabbit. In Fig. 11, the Chinese workers dance around an enormous box of Lavine soap, like elves or leprechauns around a pot of gold. Here, the new product, instead of getting rid of the aliens, fills them with joy, presumably because their work has been made easier. Figures 12 and 13 also portray products that please the Chinese laundry workers because they make their job easier (as with the wringer) or simply because the products are so nice. In such cases, the middle-class viewer is supposed to identify with the elation of the Chinese figures, just as the reader or hearer of a folktale would ostensibly identify with the protagonist. But the images also elicit ambivalent, more complex responses.

The Chinese figures' queues are figures of fascination, miniature phalluses that are, first, exposed and therefore impotent, and second, apparently out of the owner's control. In Fig. 11, the queues stand erect because the dancing figures are happy, and in Fig. 12, the queue becomes useful, a line on which to hang drying shirts. But most disturbing is Fig. 13, in which, while the Chinese woman - one of the few depictions of women in the U.S. rather than in Asia - obliviously reads a book, the Chinese laundry worker becomes entangled in the wringer. The technology that serves as the purifying sign of modernity in the previous section turns on the character who, in this narrative context, is supposed to benefit from it. Although the image does not invite identification - the figure is grotesque and the situation is painful the English caption in the vaguely Oriental script at the top of the card invites the viewer to identify with the endangered figure. It reads, "Take a cue from the Chinaman and use Empire Wringers." The slapstick haplessness of Chinese figure belies the ambivalence of the viewer's identification with the values of domestic economy and convenience and simultaneous distancing from the grotesque other. Such images also evoke the middle-class's equivocal attitude in distinguishing itself from the upper class by embracing the values of thrift, practicality, and hard work, all traits that skirt too closely to the honorable poor. 


\section{Ethnic Studies Review Volume 31}

While some images are "benign," trade cards display most comfort with depictions of Asians outside the U.S. This ilk of image usually involves not only the Chinese but "representatives" of other nations, who demonstrate awe not only at the American product but also the American producer/distributor of that product. In these images, "the cult of the great man" prevails, implicitly justifying and even calling for American imperial power. ${ }^{32}$ In the attempts to create a "racial-national purity," Figures 14 and 15 portray what Etienne Balibar calls "the (super-) national man." ${ }^{33}$ The figure speaks to the impossibility of keeping nationalist discourses within a purely national framework, and we see again that American superiority must arise from distinction with other nations, but their supposed equivalence as nations must enable this comparison in the first place.

The notion of the "great man" among a league of nations figures clearly in Figures 14 and 15, in which the icon of American nationalism, the ultimate "great man" himself, Uncle Sam, is "Supplying The World" with architectural finishes and agricultural tools. The text serves fairly straightforwardly as "anchorage" of interpretation: this is no angry international mob, but a docile, grateful group of stereotypical cultural representatives living under (literally, because Uncle Sam is at least a foot taller than anyone else) the capitalist, imperialist munificence of the U.S. In both these images, the "great man" illustrates the justification and even necessity for the world reign not only of the American state but also of American business.

Along similar lines, the Magnolia Hams series of trade cards utilized nearly every possible racial stereotype, American and international. In another trade card for Magnolia Hams (not pictured), the familiarly queued Chinese figure, now safely in China, bows and places a dead rat at the feet of the white, Western capitalist planted complacently in the center of the picture. ${ }^{34}$ The text reads, "That is a plump rat, Chang Whang, but excuse me, I always carry Magnolia Hams." This trade card portrays the Western Man as coming to liberate the Orient from the dirty, diseased rats overflowing out of the plates and pockets of the Chinese. He brings civilization, modernity, cleanliness, and technological advances, 
while in the background, a parade of international figures carry the product, Magnolia Hams, suggesting that this American man has already conquered other parts of the world and its denizens and now they serve him and his commodity.

Although national representatives are usually male, in other trade cards, universal amazement also applies to women and even babies. Again, the dialectic of sameness and difference articulates identity and the boundaries it requires. Such clear marks of certain kinds of difference, particularly the demarcation of boundaries between nations and the assertion of U.S. superiority in technological ability, provide safe ground for acknowledgement of some kinds of sameness among people - the need for certain products - that will in turn provide justification for the expanding global market.

\section{Classic Orient, Classy American}

While Robert Jay finds that images of the Japanese were used to sell luxury items, images of the classic Orient actually vary. Certainly, in general, images of Asians in the U.S. at that time take the form of caricatured Chinese laborers, while romanticized pictures of the Orient, particularly of Japanese women, are cast in the past, removed from the viewer by space and time. Yet exceptions arise, many of which still conform to T. Kim's observation that the Orient is portrayed as close to nature, simplicity, and beauty. For example, one trade card (not pictured), an Oriental child watches a bug pull a cart; this childlike picturesque advertises "Embroideries, Laces, White Goods, Real and Nottingham Lace Curtains, \&c." The image ostensibly has nothing to do with the product - these are not Asian goods - but rather draws on the cultural appeal of the Orient as aesthetic. This appeal applies both to the products, luxury items marking social class, as well as to the collectible trade card itself. At the same time, Fig. 10 above, the happily ironing Chinese laundry worker, was used to sell luxury items; the same 1882 image was also used to sell "Fine Clothing and Tailoring" in Philadelphia.

Products associated with and ostensibly from Asia also draw on images of the Orient. Stanton Ieas, based in Norwich, Connecticut, featured a series of trade cards in 1877 that depicted China as a 


\section{Ethnic Studies Review Volume 31}

land of simplicity and naturalness. In one card pictured in Fig. 16, a fruit vendor is attacked by a dog and upsets his cart. In another card, a dog has apparently caught an unfortunate person up a tree, while a complacent friend comes to his aid. Two other images depict fishermen in similarly simple, rustic settings. Such cards resolve the attraction of the rustic peasant figures by casting them into the past. The proximity of class, in other words, is negotiated by distance in terms of time and space.

Similarly, Syracuse-based C.H. Remer also uses a series of trade cards to advertise its product, "Japan and China tea store." The images show vaguely Chinese and Japanese figures making tea, "going to the tea party," and drinking tea. Figure 17 epitomizes the aestheticized, feminine, submissive Orient; the image itself takes the form of an Oriental scroll, and it is labeled "A Japanese Offering," which presumably encompasses the tea, the woman, and Asia itself. Images of Japanese women in traditional dress were also used to sell flowers, soap, and other luxury items. Since the forcible opening of Japan by the U.S. in the 1850s, Americans were fascinated with Japanese culture as a kind of pristine example of the Oriental traditional past. Gilbert and Sullivan's play "The Mikado" was extremely popular in the U.S. in the 1880s, while in the early twentieth century, the literary works of Otono Watanna (Winnifred Eaton) were much more popular than those of her sister, Sui Sui Far (Edith Maud Eaton).

But such images of the feminized Orient also served to define American womanhood. Mari Yoshihara notes that Madame Butterfly's tragic heroine Cio-Cio-San was played by white actresses who embodied American womanhood much more than Japanese femininity. ${ }^{35}$ One trade card (not pictured), featuring "Yum Yum," is one of a series of New York trade cards for Mack publishing, which touts a new book containing "the complete words and music of the most beautiful songs of the Mikado," as well as two pharmacies: R. H. McDonald Drug Company and The Royal Pharmaceutical Company. Images of a white actress in the role of "Yum Yum" were also used to sell soap. ${ }^{36}$ That the women in the images are obviously white suggests the role that such images played as large a role in creating American middle-class femininity. Such trade card 


\section{Kim-Dialectic of “Oriental” Images}

images resolve tensions between the familiar and the exotic, the Western and Oriental, the feminine Oriental other and American femininity to license certain kinds of roles and values. The Orient constituted symbolic capital but only as wielded by white middleclass American femininity, not as actually constituted by Asian Americans.

The objectives of such trade cards were many and multifaceted. Most obviously, their purpose was to sell products, including the trade cards themselves by printing companies. As such, the cards participate in the increasing infiltration of the commercial into the domestic sphere and "private" spaces (resulting in the practical saturation that we experience today). But like much ephemera, the cards were also a means for Americans to reflect themselves symbolically to themselves. Such everyday objects function "indirectly" because they fold into their foremost ostensible purpose - advertising products and services - multiple, not always coherent functions. The new technology and expanding markets enabling the dissemination of these kinds of advertisements coincided with the expanding middle class's project of defining itself. These relatively mundane trade cards served as symbolic currency in the middle-class negotiation of self-determination against the lower and upper classes, even as they participated in the institutional and symbolic circumscriptions of life for Asian Americans. The cards were also part of a larger symbolic field in which Americans - again, particularly middle-class ones - resolved tensions about modernity and primitiveness, equality and hierarchy, and sameness and otherness.

That the trade cards were pitched primarily to middle-class Americans suggests that the middle class' response to racial others was distinct from that of the upper and lower classes. Certainly, most classes shared some form of xenophobia and anxiety about sexuality. But overall, the middle class was not more or less racist but often both - or rather, the middle class's construction of race could be distinguished from others. Due to their intermediary and uncertain position, the middle class had a stronger desire to distinguish itself both from Asians and other Americans, as suggested in Fig. 3 and 4. At the same time, foreshadowing the 


\section{Ethnic Studies Review Volume 31}

"model minority" myth of the late twentieth century, those others could be attributed with shared values of identification of thrift and work ethic, as demonstrated in Fig. 9 and 10. The middle-class' relation to Asians, in fact, was often contrasted with what was seen as lower-class brutality against immigrants. As Fig. 14 and 15 demonstrate, it was acceptable to recognize Asians as one among a number of nations with similar needs, but this acknowledgement depended on the simultaneous demarcation of these others as primitive, separate, and distanced. Trade cards were thus part of the system of "visual regulation" of immigrants that Anna PeglerGordon notes became crucial in the nineteenth and early twentieth centuries, ${ }^{37}$ but they were also central to the various dialectical negotiations involved in the American middle-class's creation of itself. 
Kim-Dialectic of "Oriental” Images

\section{“THE DIALECTICS OF 'ORIENTAL' IMAGES IN AMERICAN TRADE CARDS” TRADE CARD IMAGES}

Fig. 1 Trade Card Collection, \#4524. Courtesy of the Division of Rare and Manuscript Collections, Cornell University Library.

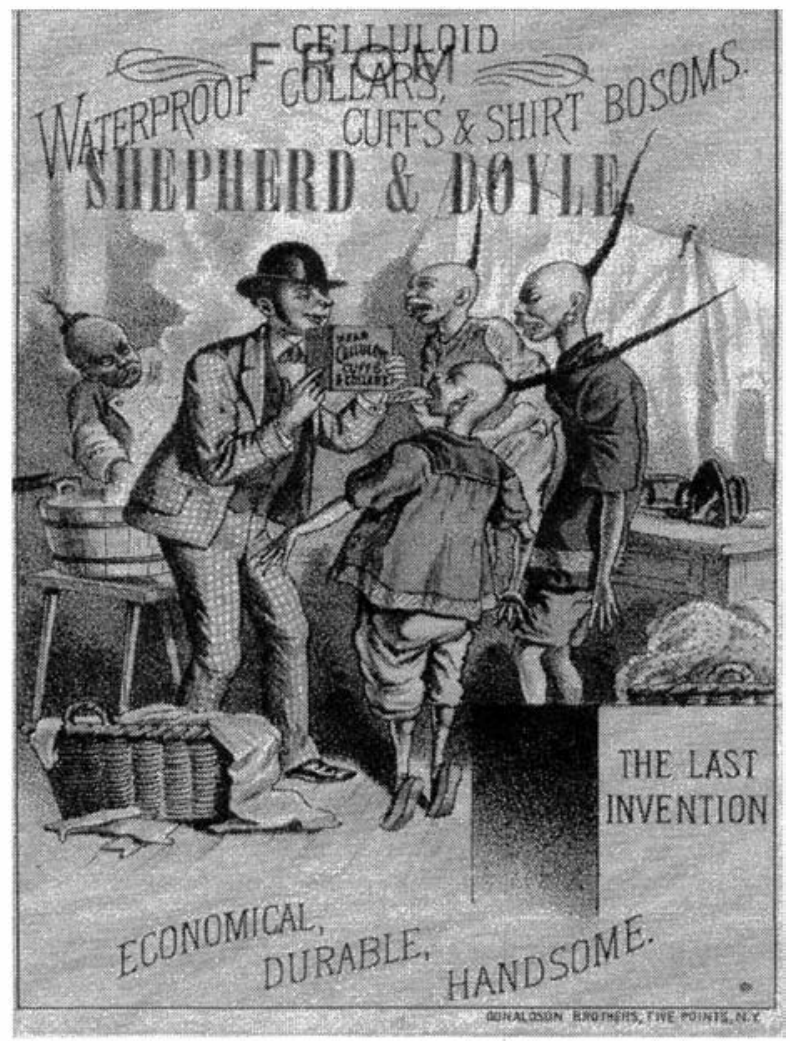




\section{Ethnic Studies Review Volume 31}

Fig. 2 Warshaw Collection of Business Americana - Men's Clothing, Archives Center, National Museum of American History, Smithsonian Institution

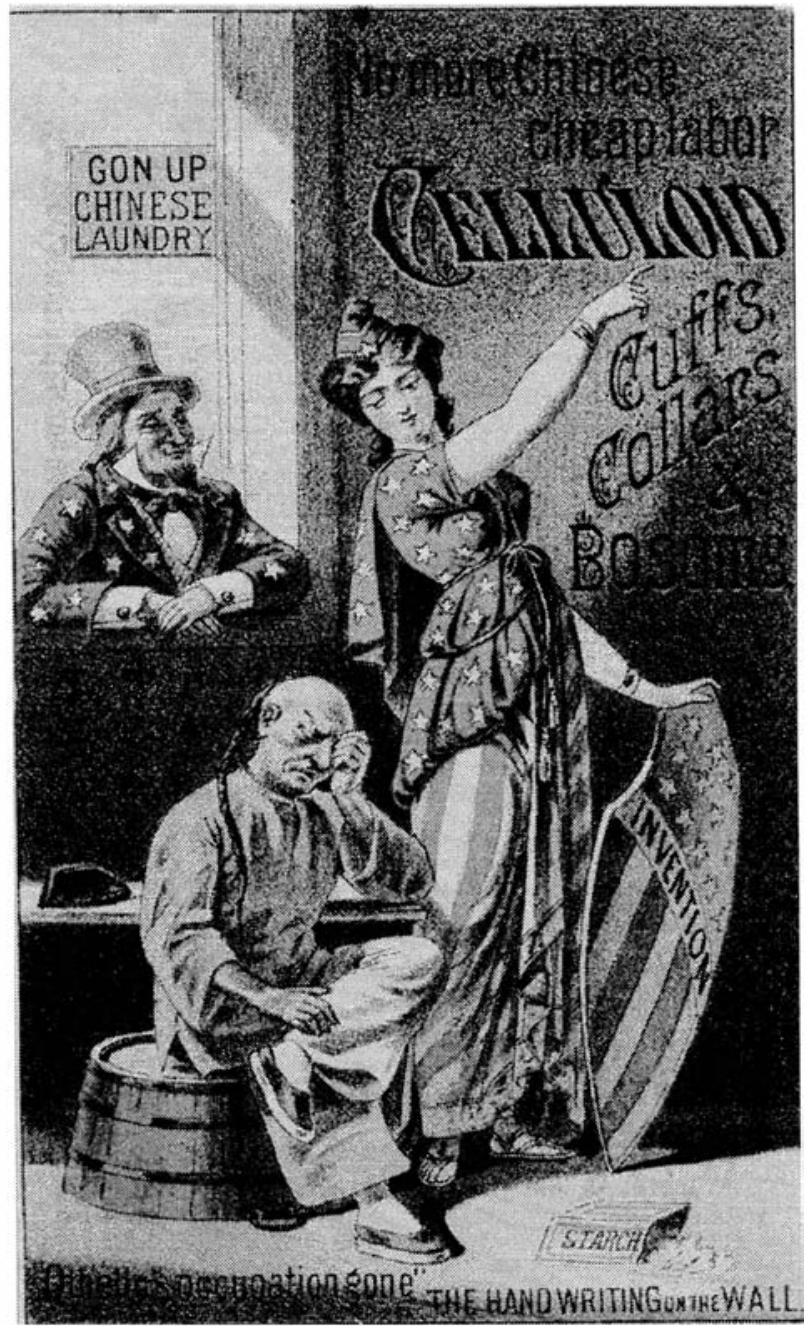


Kim-Dialectic of "Oriental” Images

Fig. 3 Warshaw Collection of Business Americana - Men's Clothing, Archives Center, National Museum of American History, Smithsonian Institution

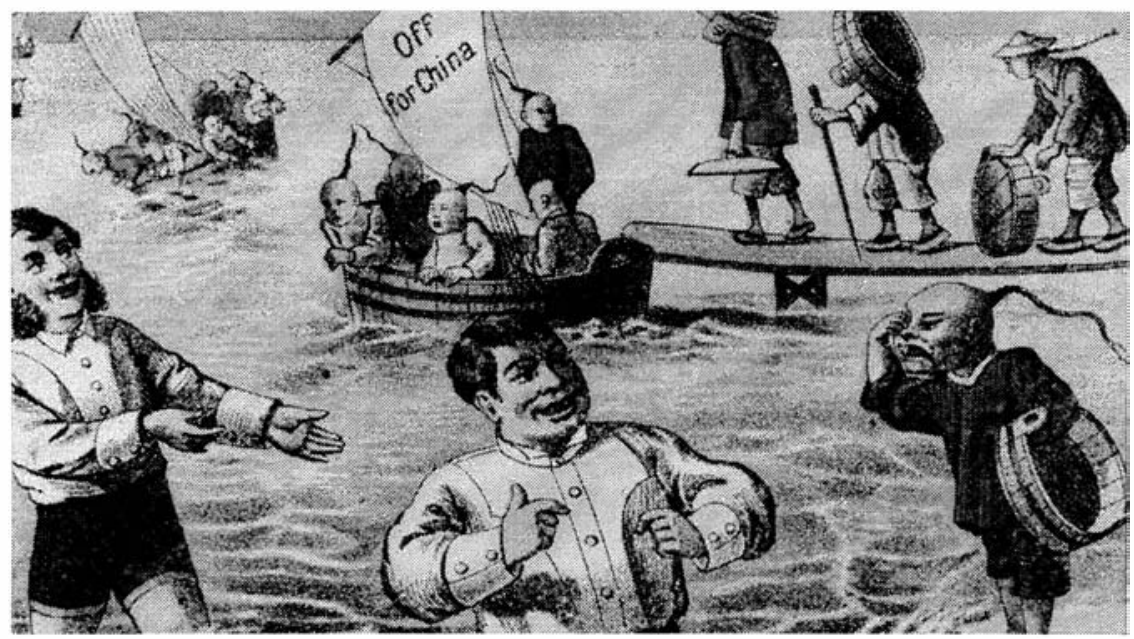

Fig. 4 Warshaw Collection of Business Americana - Men's Clothing, Archives Center, National Museum of American History, Smithsonian Institution

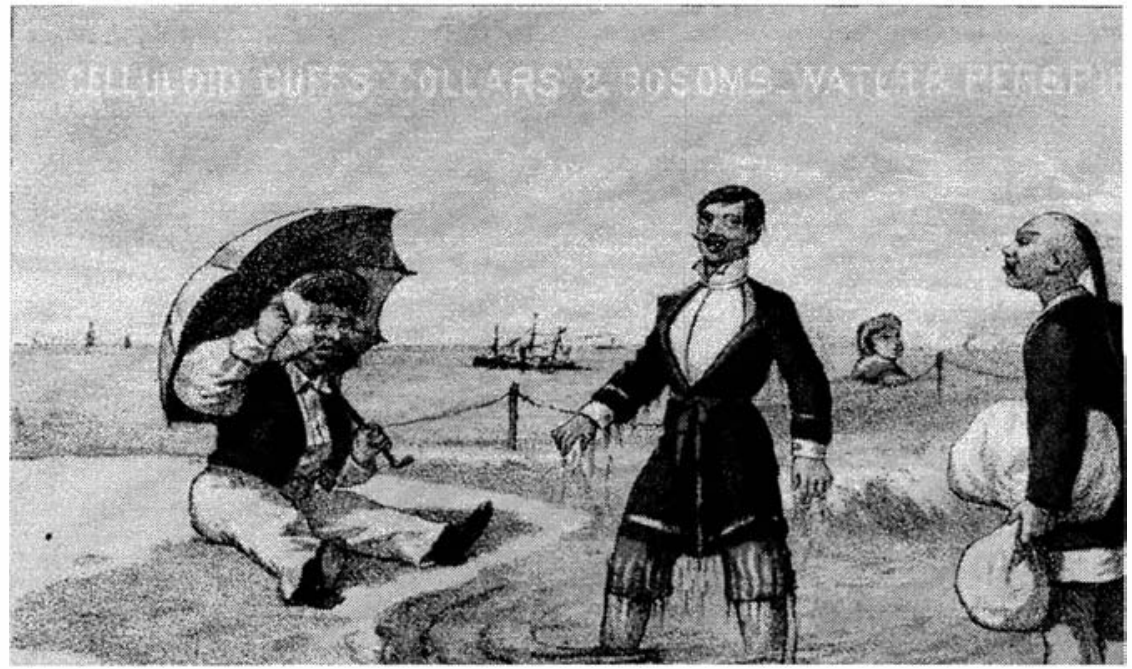




\section{Ethnic Studies Review Volume 31}

Fig. 5 Warshaw Collection of Business Americana - Men's Clothing, Archives Center, National Museum of American History, Smithsonian Institution

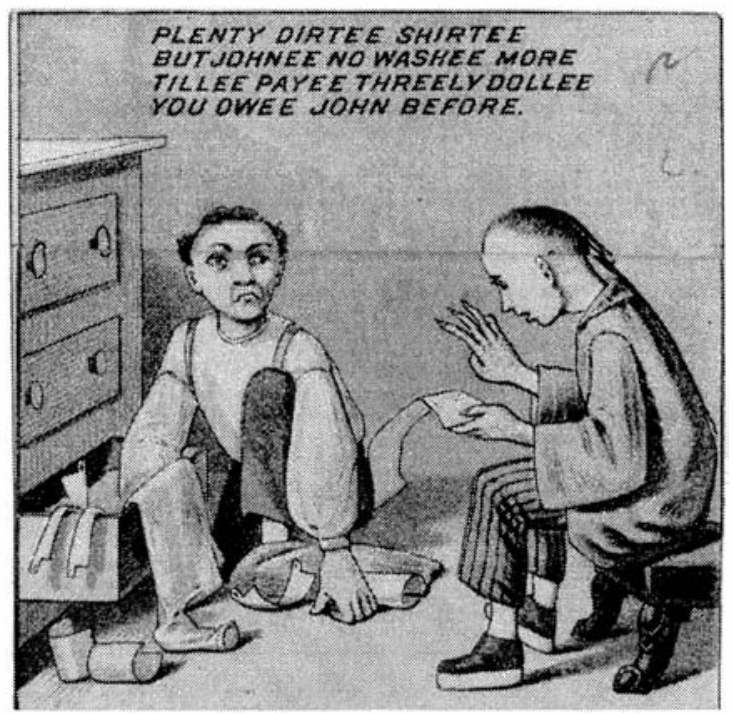

Fig. 6 Warshaw Collection of Business Americana - Men's Clothing, Archives Center, National Museum of American History, Smithsonian Institution

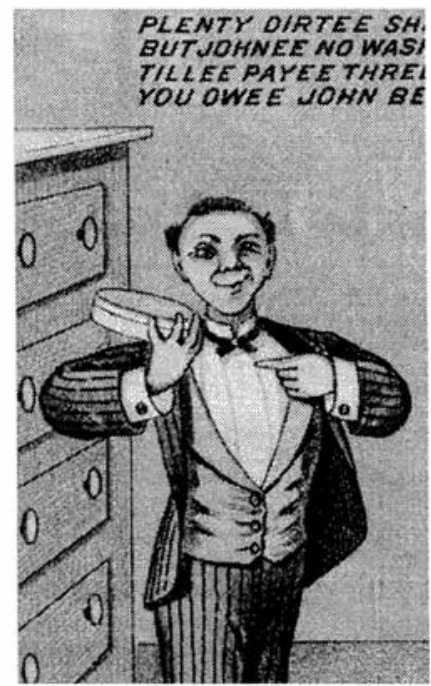


Fig. 7 Warshaw Collection of Business Americana - Laundry, Archives Center, National Museum of American History, Smithsonian Institution

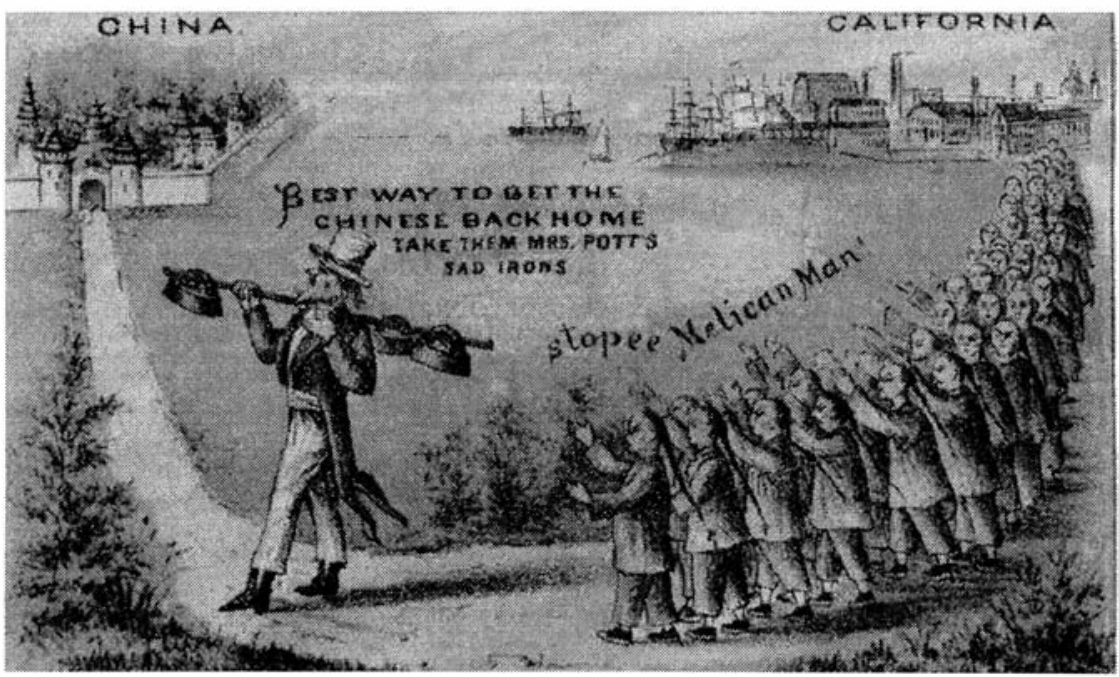

Fig. 8 Warshaw Collection of Business Americana - Laundry, Archives Center, National Museum of American History, Smithsonian Institution

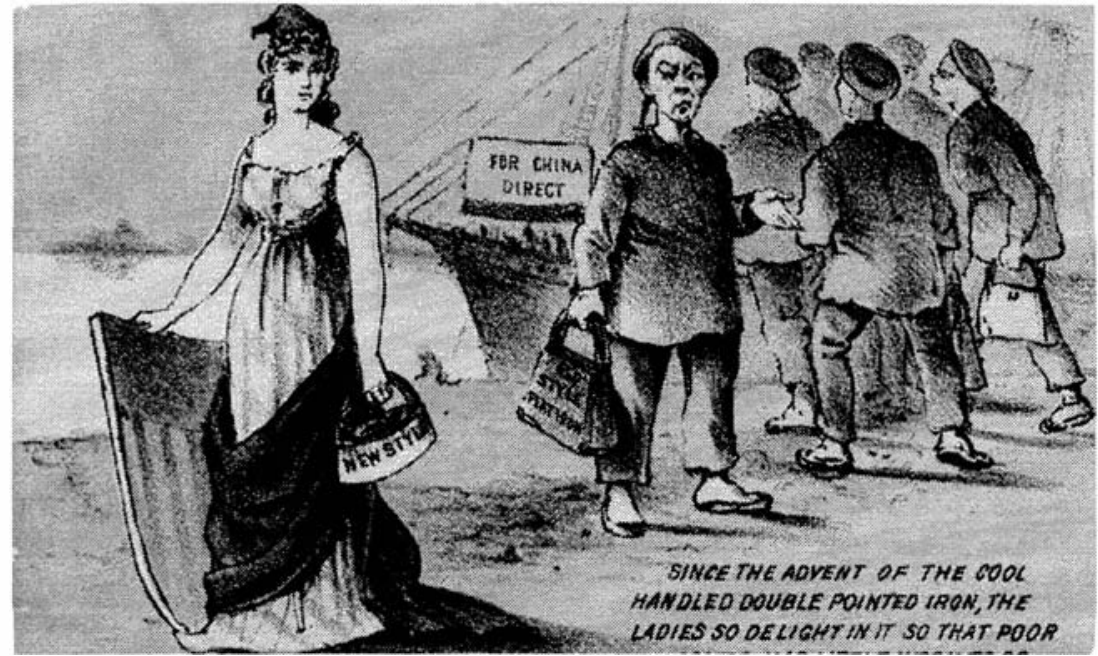




\section{Ethnic Studies Review Volume 31}

Fig. 9 Trade Card Collection, \#4524. Courtesy of the Division of Rare and Manuscript Collections, Cornell University Library.

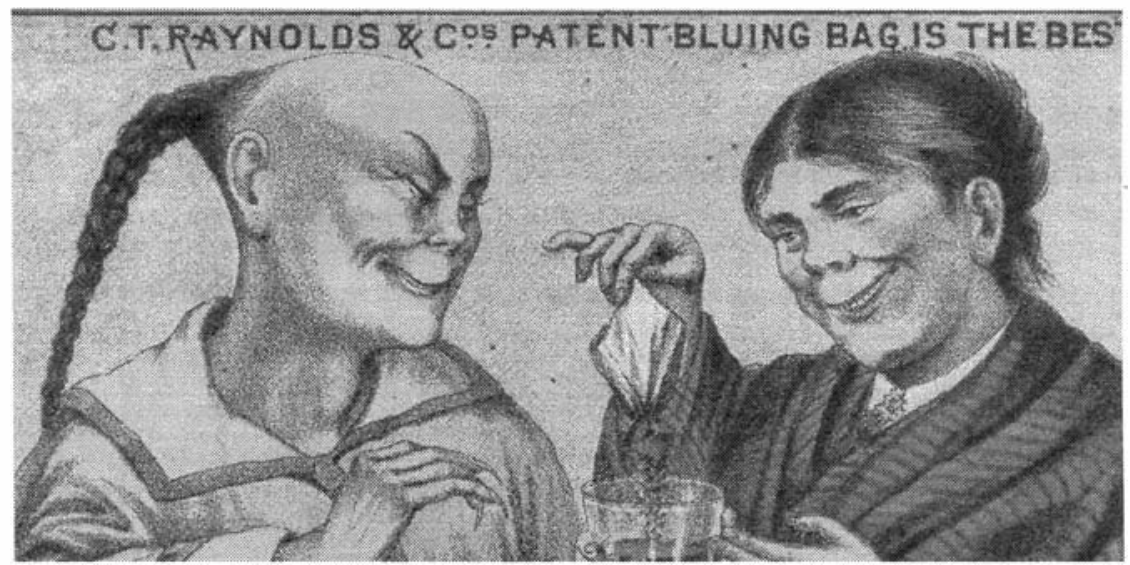

Fig. 10 Warshaw Collection of Business Americana - Cosmetics, Archives Center, National Museum of American History, Smithsonian Institution

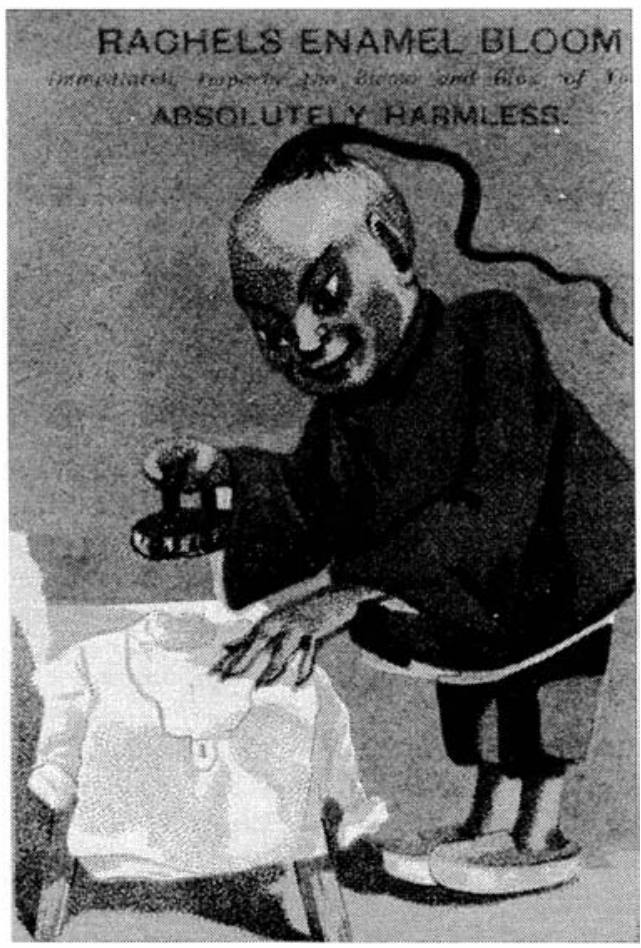




\section{Kim-Dialectic of “Oriental” Images}

Fig. 11 Warshaw Collection of Business Americana - Soap, Archives Center, National Museum of American History, Smithsonian Institution

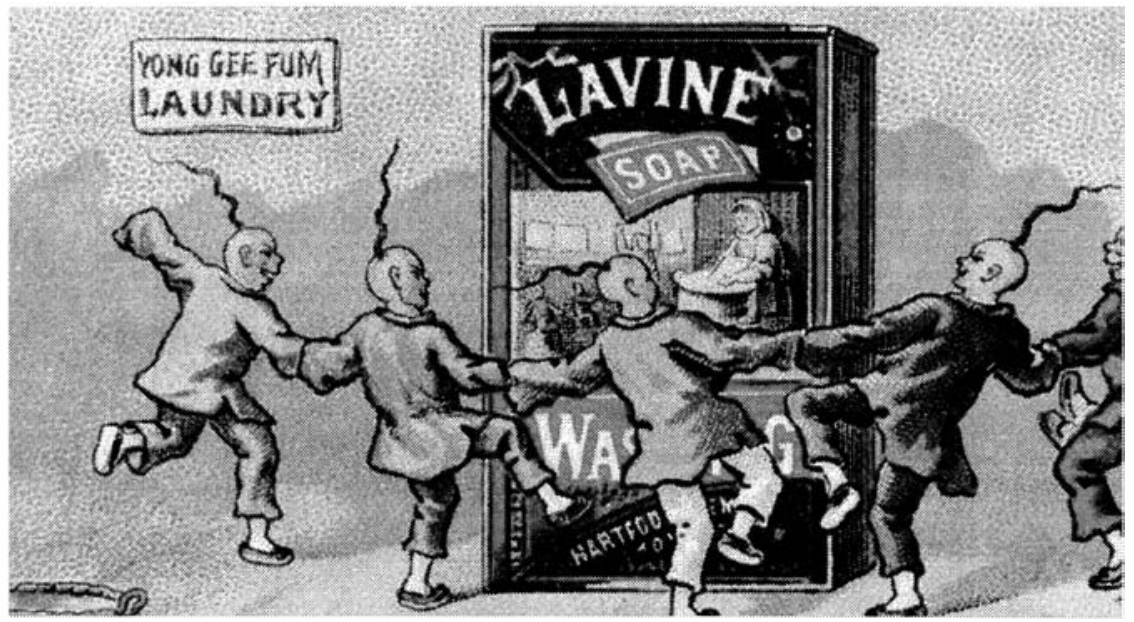

Fig. 12 Warshaw Collection of Business Americana - Men's Clothing, Archives Center, National Museum of American History, Smithsonian Institution

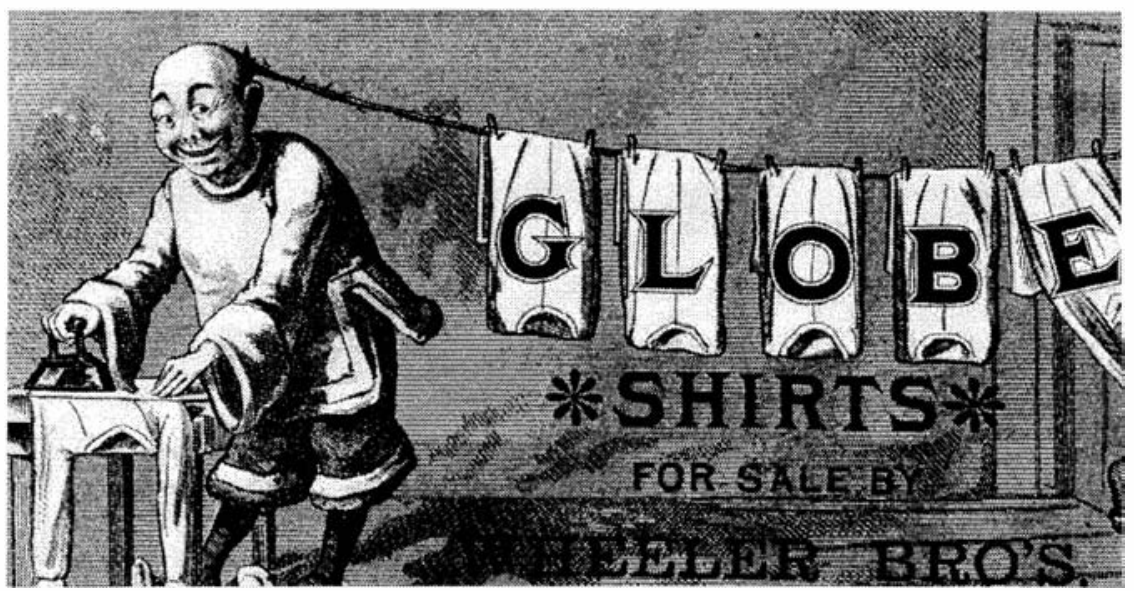




\section{Ethnic Studies Review Volume 31}

Fig. 13 Warshaw Collection of Business Americana - Laundry, Archives Center, National Museum of American History, Smithsonian Institution

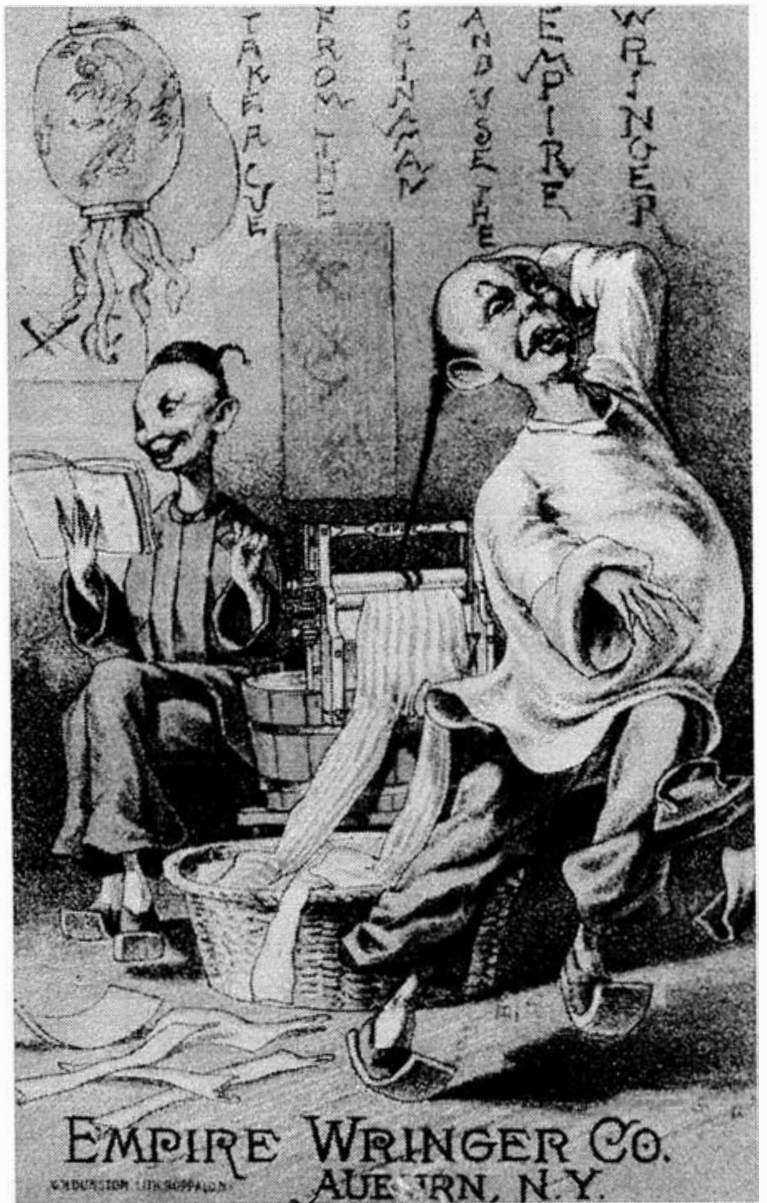




\section{Kim-Dialectic of “Oriental” Images}

Fig. 14 Warshaw Collection of Business Americana - Agriculture, Archives Center, National Museum of American History, Smithsonian Institution

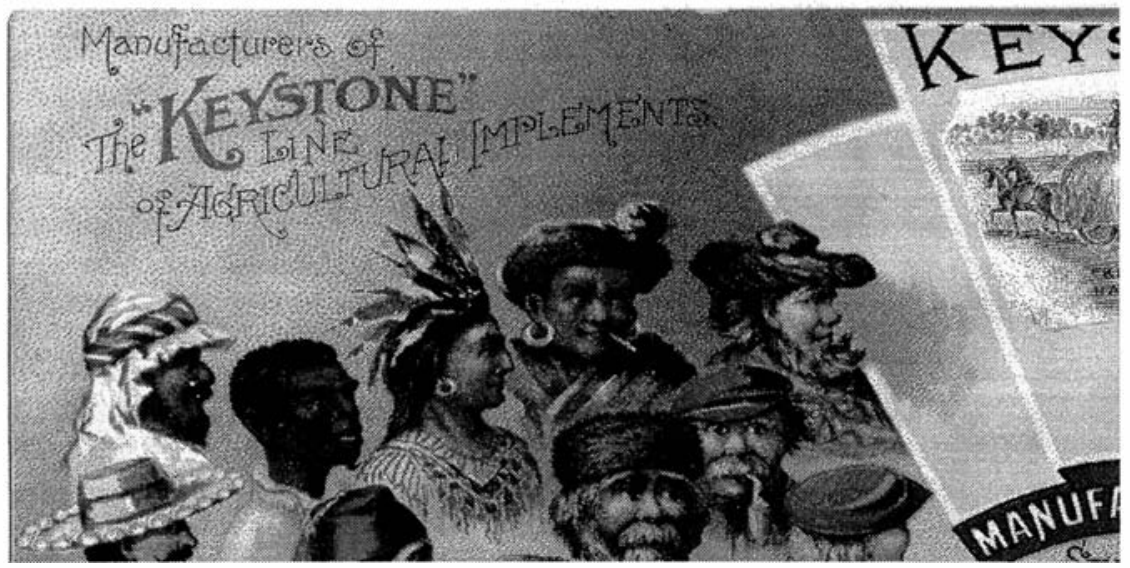

Fig. 15 Trade Card Collection, \#4524. Courtesy of the Division of Rare and Manuscript Collections, Cornell University Library.

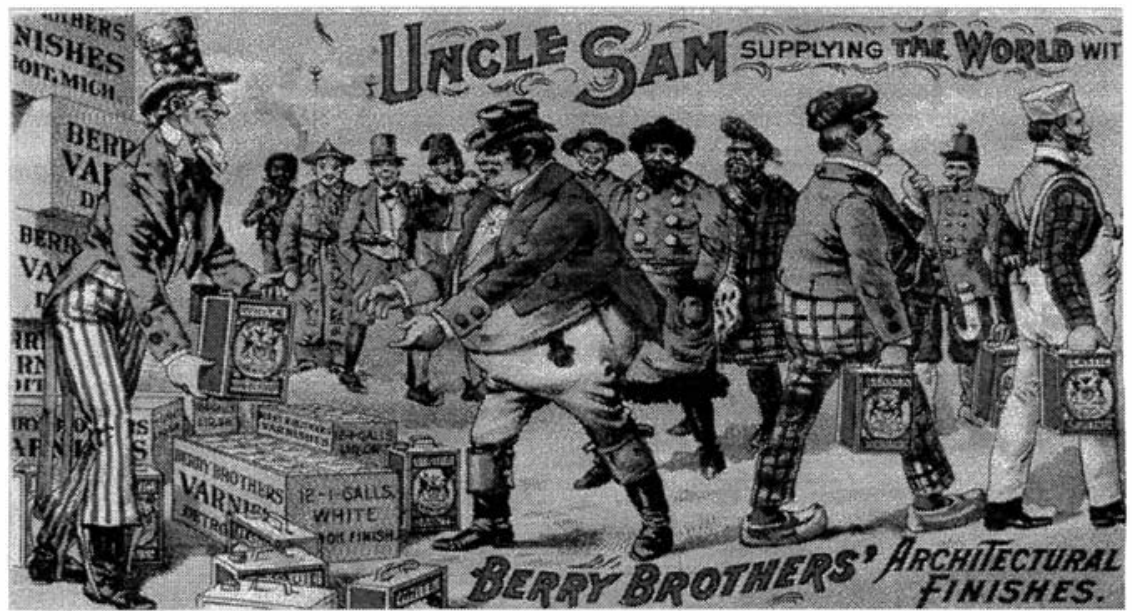




\section{Ethnic Studies Review Volume 31}

Fig. 16 Warshaw Collection of Business Americana-Tea, Archives Center, National Museum of American History, Smithsonian Institution

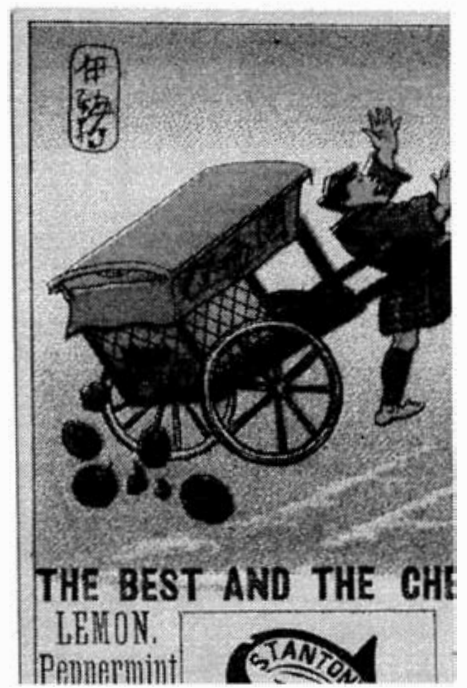

Fig. 17 Warshaw Collection of Business Americana - Tea, Archives Center, National Museum of American History, Smithsonian Institution

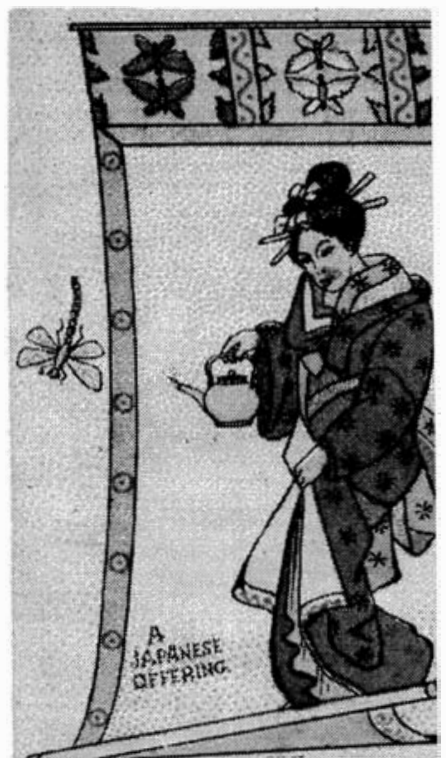




\section{Kim-Dialectic of "Oriental" Images}

\section{Notes}

1 All trade card images are used by permission of the Division of Rare and Manuscript Collections, Cornell University Library, Ithaca, NY, and the Warshaw Collection of Business Americana, Archives Center, National Museum of American History, Behring Center, Smithsonian, Washington, D.C. I would like to thank Mary White for her assistance with this project.

2 A note on terminology: In this essay, I will use the term "Orientals" and "the Orient" to refer to the generalized conception of Asian, "Chinese" for images of Chinese, "Japanese" for images of Japanese, understanding that in my discussion, these terms refer to signs, not the actual Asian Americans who, nevertheless, had and have to negotiate these signs.

3 Thomas W. Kim, "Being Modern: The Circulation of Oriental Objects," American Quarterly 58.2 (June 2006), 385-6.

4 Robert Jay, The Trade Card in Nineteenth-Century America (Columbia: University of Missouri Press, 1987), 74.

5 M. Thomas Inge, ed., Handbook of American Popular Culture, Vol. 1, 2nd ed. (New York: Greenwood, 1989), 4-11.

6 J. Worth Estes, "Selling Massachusetts Medicines," Historical Journal of Massachusetts 14.2 (1986): 123. Estes discusses the role trade cards for patent medicines played in the enactment of the 1906 Pure Food and Drug Act, another indication of the social significance of these little items.

7 Jay, 34-37. Other forms of media, such as newspaper and magazines, included advertisements but were limited to black and white images, and set restrictions on space and product. For example, many publications would not advertise beer and liquor, and advertisements were placed in the back section of the publications.

$8 \mathrm{lbid}$., 1. This also coincides with the work of a number of scholars who have debunked the notion that anti-Asian sentiment during the late nineteenth century arose primarily from the working classes in California. The construction of "the Oriental" in the West preceded significant immigration of Asians to the West, was a national phenomenon, and was manipulated - like all images in advertising - according to the geopolitical and economic needs of the moment. See Gary Okihiro, Margins and Mainstreams (Seattle: $U$ of Washington, 1994); Stuart Creighton Miller, The Unwelcome Immigrant: The American Image of the Chinese, 1785-1882 (Berkeley: U of California, 1969); and Alexander Saxton, The Indispensable Enemy: Labor and the Anti-Chinese Movement of California (Berkeley: $U$ of California, 1971). Gary Okihiro provides a delineation of attitudes towards Asian immigration in The Columbia Guide to Asian American History (New York: Columbia UP, 2001). 


\section{Ethnic Studies Review Volume 31}

9 Ibid., 3. For more general information on the history of trade cards, see Ambrose Heal, London Tradesmen's Cards: An Account of Their Origins and Use (London: B.T. Batsford, 1925); Bella C. Landauer, Early American Trade Cards (New York: William Edwin Rudge, 1927); Richard Ohmann, Selling Culture: Magazines, Markets, and Class at the Turn of the Century (London: Verso, 1996); and Maurice Rickards and Michael Twyman, eds., Encyclopedia of Ephemera (London: The British Library, 2000).

10 Anne McClintock, Imperial Leather: Race, Gender, and Sexuality in the Colonial Contest (New York: Routledge, 1995), 213.

11 Ibid., 209.

12 Ibid., 5.

13 Lisa Lowe, Immigrant Acts: On Asian American Politics (Durham: Duke UP, 1996), 176.

14 Walter Benjamin, "The Work of Art in the Age of Mechanical Reproduction," Illuminations, Ed. Hannah Arendt, Trans. Harry Zohn (1955; New York: Schocken Books, 1968).

15 Elizabeth Kim, "Race Sells: Racialized Trade Cards in 18th-Century Britain," Journal of Material Culture 7.2 (July 2002): 137-165.

16 Ohmann, 264.

17 Jennifer Wicke, Advertising Fictions: Literature, Advertisement, and Social Reading (New York: Columbia University Press, 1988): 16.

18 Linda Frost, Never One Nation: Freaks, Savages, and Whiteness in U.S. Popular Culture, 1850-1877 (Minneapolis: University of Minnesota Press, 2005).

19 David Harvey, The New Imperialism (Oxford: Oxford University Press, 2003), chapter 2; Giovanni Arrighi, The Long Twentieth Century: Money, Power, and the Origins of our Times (London: Verso, 1994), 33-34.

20 Ohmann, 170.

21 Ibid., 167-8, 171-2.

22 Ibid., 167.

23 T. Kim, 387.

24 Moon-Ho Jung, "Outlawing 'Coolies': Race, Nation, and Empire in the Age of 


\section{Kim-Dialectic of “Oriental” Images}

Emancipation," American Quarterly 57.3 (Sept. 2005): 677-701.

25 Miller, 191-192.

26 See Gary Okihiro, Margins and Mainstreams: Asians in American History and Culture (Seattle: $U$ of Washington, 1994) 3, 25-6; Okihiro, "Reading Asian Bodies, Reading Anxieties," lecture, Ethnic Studies Colloquium, University of California, San Diego (Nov. 2, 1995); David Eng, Racial Castration: Managing Masculinity in Asian America (Durham: Duke UP, 2001); Paul Siu, The Chinese Laundryman: A Study of Social Isolation, Ed. John Kuo Wei Tchen (New York: New York UP, 1987); and, more in the twentieth-century, Nayan Shah, "Between 'Oriental Depravity' and 'Natural Degenerates': Spatial Borderlands and the Making of Ordinary Americans," American Quarterly 57.3 (Sept. 2005): 703725; and Jay Geller, "Judenzopf/Chinesenzopf: Of Jews and queues," positions 2.3 (Winter 1994): 500-538.

27 McClintock, 220.

28 Ibid., 223.

29 Rose Hum Lee, The Growth and Decline of Chinese Communities in the Rocky Mountain Region (1947; New York: Arno, 1978).

30 But like the writing on the walls at Angel Island, this Chinese worker's writing remains mysterious and unread.

31 Roland Barthes famously theorized the ideological work of image and text in interplay in "Rhetoric of the Image." Barthes argues that the language of images consists of "idiolects, lexicons and sub-codes," and "the image is penetrated through and through by the system of meaning" (47). Images are "polysemous," i.e. "they imply, underlying their signifiers, a 'floating chain of signifieds,' the reader able to choose some and ignore others" (47). Text guides interpretation of images, "constituting a kind of vice which holds the connoted meanings from proliferating" (39). He identifies two functions at work in a text: anchorage and relay. Anchorage "directs the reader through the signifieds of the image...by means of a subtle dispatching, it remote-controls him towards a meaning chosen in advance" (40-1). At this level, "morality and ideology of a society are above all invested." In relay, "text... and image stand in a complementary relationship; the words... are fragments of a more general syntagm and the unity of the message is realized at a higher level"; for example, comic strips function through relay (401). Barthes, Roland, "Rhetoric of the Image," Image, Music, Text, Trans. Stephen Heath (New York: Hill \& Wang, 1977): 32-51.

32 Ohmann, 345.

33 Etienne Balibar and Immanuel Wallerstein, Race, Nation, Class: Ambiguous Identities, Trans. Chris Turner (London: Verso, 1977), 61. 


\section{Ethnic Studies Review Volume 31}

34 This trade card is not pictured because the original has - alas! - gone missing from the Kroch Library Archives Trade Card collection.

35 Mari Yoshihara, "The Flight of the Japanese Butterfly: Orientalism, Nationalism, and Performances of Japanese Womanhood," American Quarterly 56.4 (Dec. 2004): 975-1001.

36 Ohmann, 74.

37 Anne Pegler-Gordon, "Chinese Exclusion, Photography, and the Development of U.S. Immigration Policy," American Quarterly 58.1 (March 2006): 51-77. 